\title{
First records of Brazilian three-banded armadillo (Tolypeutes tricinctus, Mammalia, Cingulata, Chlamyphoridae) predation by jaguar (Panthera onca, Mammalia, Carnivora, Felidae)
}

\author{
Rodolfo Assis Magalhães ${ }^{1,2}$; Liana Mara Mendes de Sena ${ }^{1,3}$ \& Flávio Henrique Guimarães Rodrigues ${ }^{1,4}$ \\ ${ }^{1}$ Universidade Federal de Minas Gerais (UFMG), Instituto de Ciências Biológicas (ICB), Departamento de Genética, Ecologia e Evolução (DGEE), \\ Laboratório de Ecologia de Mamíferos. Belo Horizonte, MG, Brasil. \\ 2 ORCID: http://orcid.org/0000-0002-6876-8521. E-mail: rodolfoassismagalhaes@gmail.com \\ 3 ORCID: http://orcid.org/0000-0002-1364-1769. E-mail: lianamms@gmail.com \\ ${ }^{4}$ ORCID: http://orcid.org/0000-0002-4797-0085. E-mail: rodriguesfhg@gmail.com
}

\begin{abstract}
The jaguar Panthera onca and the Brazilian three-banded armadillo Tolypeutes tricinctus are two threatened mammals that coexist in the Caatinga dry forests and the Cerrado savannas of Brazil. Yet, to the best of our knowledge, interactions between these species have not been reported in the literature. Here, we present the first records of $P$. onca predation on T. tricinctus from two different areas in the Caatinga in northeastern Brazil. We showed that $P$. onca can pierce the hard carapace of $T$. tricinctus, which may be possible due to its distinctly strong bite and associated predation behavior. We argue that $P$. onca may be the most adapted non-human predator to feed on T. tricinctus, and that the smaller body sizes of $P$. onca individuals in the Caatinga may increase their likelihood to feed on smaller prey, including T. tricinctus. Thus, the originality of our records is probably more related to insufficient research in the areas where these species coexist than to the rarity of this interaction.
\end{abstract}

Keywords. Bahia; Diet; Predator-prey interaction; Serra da Capivara National Park; Seasonally Dry Tropical Forest.

\section{INTRODUCTION}

The jaguar Panthera onca (Linnaeus, 1758) and the Brazilian three-banded armadillo Tolypeutes tricinctus (Linnaeus, 1758) are two threatened mammals that coexist in the Caatinga and Cerrado domains in Brazil (Bocchiglieri et al., 2010; Astete et al., 2017). T. tricinctus is one of the two species of the genus Tolypeutes, along with Tolypeutes matacus (Desmarest, 1804) (Wetzel et al., 2008). These species are among the smallest Brazilian armadillos and are unique in presenting the ability to roll up their bodies into a ball (Wetzel et al., 2008). When rolled up, Tolypeutes protect their softer tissues with their hard, ossified tegument, thereby providing protection against predation (Wetzel et al., 2008; Superina \& Loughry, 2012).

Tolypeutes tricinctus is the only armadillo endemic to Brazil and is restricted to the Caatinga and Cerrado domains (Feijó et al., 2015). The species is facing a significant decline in its populations due to hunting and habitat loss, which led it to be classified as Endangered in Brazil (Reis et al., 2015).
Nevertheless, little is still known about its biology (Superina et al., 2014; Reis et al., 2015). For instance, as far as we know, there is no published study that presented evidence of T. tricinctus predation by other native predators, although it has been considered a potential prey for larger felids (Astete et al., 2017). This scenario led T. tricinctus to be classified as a top-priority armadillo species for research and conservation initiatives (Superina et al., 2014).

Panthera onca is the largest felid in America, occurring from south to north of the continent, where it inhabits numerous ecosystems (Sanderson et al., 2002; Morato et al., 2013). In Brazil, $P$. onca is found in almost all domains, including the Caatinga, where the species is classified as Critically Endangered as a result of habitat loss and hunting (Morato et al., 2013).

The diet of $P$. onca comprises more than a hundred species, with a preference for larger prey (Hayward et al., 2016). However, prey selection by $P$. onca depends on abundance and herd size more than body mass (Hayward et al., 2016). Armadillos, such as Dasypus novemcinctus Linnaeus, 1758 and 


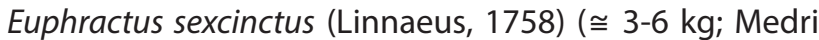
et al., 2011) can be the most consumed prey (Foster et al., 2010; Miranda et al., 2018), whereas smaller ar-

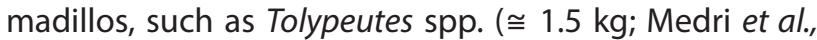
2011) are rarely documented in the literature (Hayward et al., 2016). Nevertheless, T. matacus has been found in P. onca diet (Taber et al., 1997; McBride et al., 2010), while T. tricinctus has not. Here, we present the first records of T. tricinctus predation by $P$. onca from two areas in northeastern Brazil, thereby providing evidence of a predator-prey relationship between these two threatened species and contributing to the knowledge on $P$. onca diet and $T$. tricinctus natural predators.

\section{MATERIAL AND METHODS}

The records presented here were obtained in two areas situated in the Caatinga, a semiarid phytogeographical domain predominantly covered by Seasonally Dry Tropical Forests (SDTF) distributed throughout northeast Brazil (Silva et al., 2017). We recorded the interaction once in the municipality of Brotas de Macaúbas (hereaf- ter, BdM), state of Bahia (Fig. 1), while monitoring threatened felids between August and September 2017. At the occasion, we placed 20 camera traps in pairs at 10 sites throughout a $53-\mathrm{km}^{2}$ area composed of shrubby-arboreal SDTF, former croplands in regeneration covered by ruderal vegetation, roads, and a complex of three adjacent wind farms. The sampling lasted 15 days, and we set cameras to operate 24 hours a day, with one-minute intervals between consecutive 15-second-long videos.

The other record was opportunistically obtained at the Serra da Capivara National Park (hereafter, SCNP), a $1,291-\mathrm{km}^{2}$ Protected Area located in the state of Piauí, Brazil (Fig. 1), during field activities to document the distribution of armadillos. The SCNP houses an important remnant of conserved Caatinga, comprising from sparse, bushy formations rich in cacti and bromeliads to dense arboreal SDTF (Olmos, 1992).

\section{RESULTS AND DISCUSSION}

The record from BdM was obtained on September $1^{\text {st }}$, 2017, at 06:49 pm (Fig. 2). The camera trap site was in a

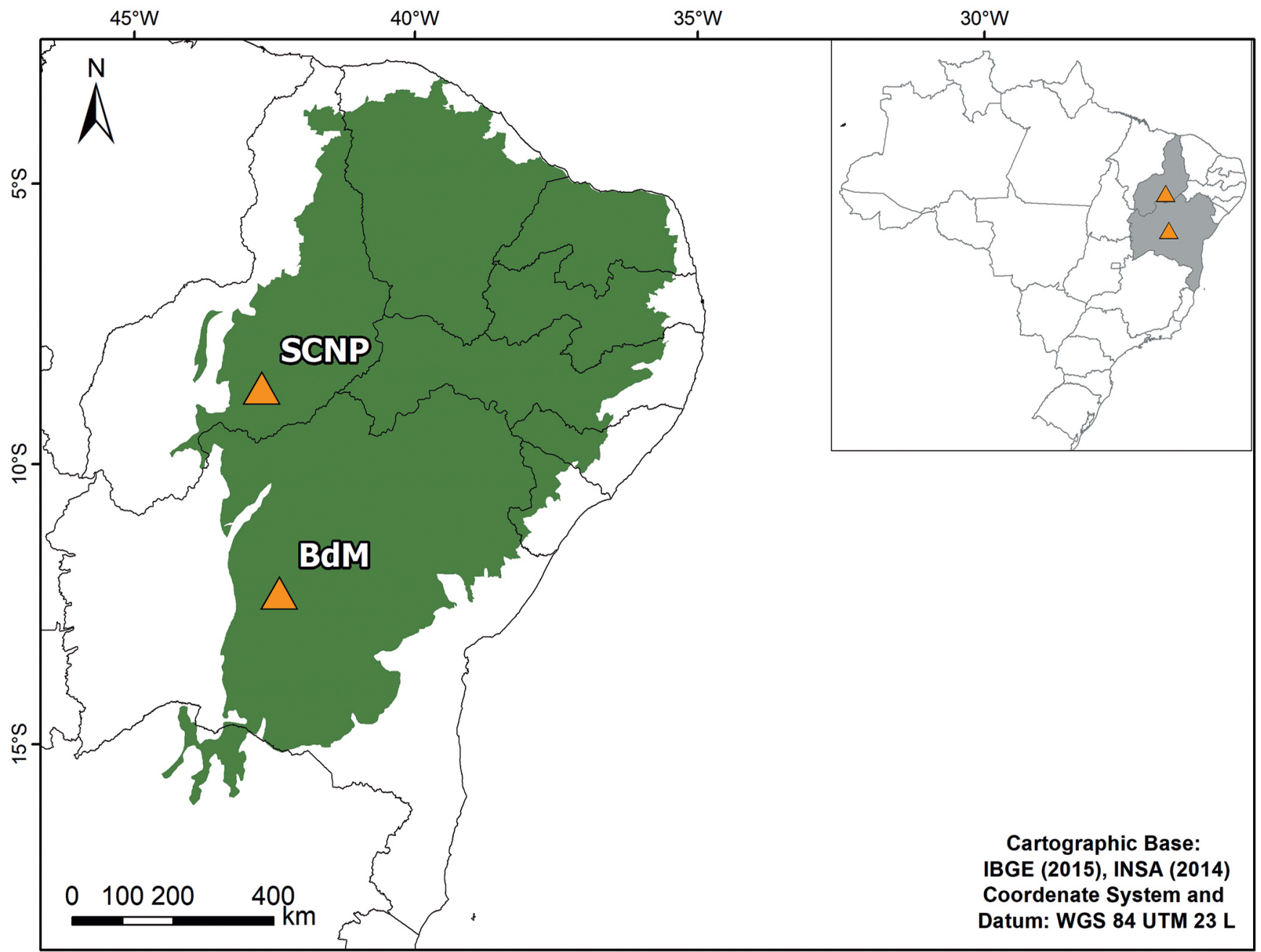

Figure 1. Location of the two areas (orange triangles) where the predation of Brazilian three-banded armadillo (Tolypeutes tricinctus) by jaguar (Panthera onca) was recorded in the Caatinga domain (green shaded area) in northeastern Brazil: Serra da Capivara National Park (SCNP) and an unprotected rural area in the municipally of Brotas de Macaúbas (BdM). The inset shows the two areas in relation to Brazilian states (gray shaded states refer to those in which the areas are located). The state divisions are from IBGE (2015), and the distribution of the Caatinga is from INSA (2014). 


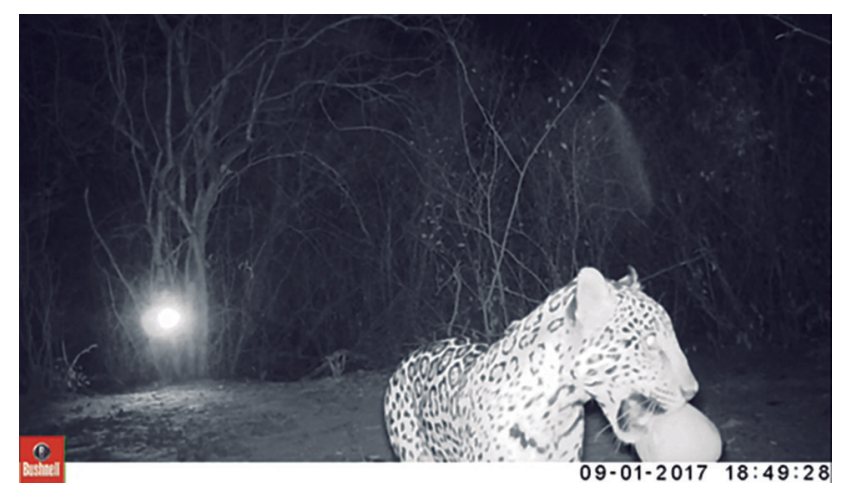

Figure 2. Record of a jaguar (Panthera onca) carrying a Brazilian three-banded armadillo (Tolypeutes tricinctus) in its mouth in the municipally of Brotas de Macaúbas, state of Bahia, Brazil. This photo is from a 15-second-long video recorded by camera trapping.

small trail sometimes used by local people, covered by shrubby vegetation and close to roads and wind turbines $\left(12^{\circ} 17^{\prime} 26.94^{\prime \prime} \mathrm{S}, 42^{\circ} 21^{\prime} 45.84^{\prime \prime} \mathrm{O}\right)$. The video shows a $P$. onca individual carrying a T. tricinctus individual in its mouth. T. tricinctus was completely rolled up in its defensive position, and $P$. onca was holding it by the left canines.

The record from SCNP consists of a damaged T. tricinctus carapace (Fig. 3A) collected on June $9^{\text {th }}, 2017$, in a densely forested site, at the Serra Branca locality, in the south portion of SCNP $\left(08^{\circ} 38^{\prime} 13.08^{\prime \prime} \mathrm{S}, 42^{\circ} 42^{\prime} 46.66^{\prime \prime} \mathrm{O}\right)$. The material was deposited in the collection of mammals of the Federal University of Minas Gerais, Brazil, under the accession number 4394.

Different factors led to the differential diagnosis for P. onca predation for the damaged carapace. Some scutes of the scapular shield were broken (Fig. 3B), and they fit the canines of $P$. onca (Fig. $3 C$ ). When the carapace was collected in the field, these scutes constituted the only damaged region of the scapular shield; the other missing scutes were probably accidentally removed by posterior manipulation and transport or deterioration of the material. More distinct, the perforation in the pelvic shield fits $P$. onca canines (Fig. 3D), although some scutes are also missing. When the carapace is positioned half-rolled (simulating the defense mechanism) against a $P$. onca skull, the jaws fit both damaged areas while respecting the maximum mandibular opening (Fig. 3E).

Furthermore, $P$. onca has one of the strongest bites and the most robust canine teeth among the extant felids for their body sizes (Christiansen \& Adolfssen, 2005; Christiansen, 2007; Meachen-Samuels \& van Valkenburgh, 2009). These features are considered adaptations to prey on larger animals (Hayward et al., 2016), but also to attack by biting hard tissues, such as by braincase piercing or by cracking open the shells of tortoises (Meachen-Samuels \& van Valkenburgh, 2009). Hence, they allow $P$. onca to prey on species that rely on armor as a defense mechanism (Miranda et al., 2016), which is the case of chelonians (Brito et al., 2018) and Tolypeutes spp. Consequently, $P$. onca is the most probable predator that could use a bite on the hard carapace of these armadillos to feed on them. In other words, while the hardness of Tolypeutes carapace may be efficient to avoid predation by other predators, it should be less efficient in avoiding predation by $P$. onca.

Such armor inefficiency is considered a possible reason why armadillos can be avoided by Puma concolor (Linnaeus, 1771), while not by Panthera onca where these predators coexist (Novack et al., 2005), which is the case of SCNP (Astete et al., 2017). Besides, armadillos are significantly more consumed by Panthera onca than by Puma concolor, probably for the same reason (Miranda et al., 2016). Nevertheless, T. matacus remnants have already been found in Puma concolor scats (Taber et al., 1997). Therefore, even though predation by other animals might occur, Panthera onca seems to be the most adapted predator to feed on Tolypeutes spp. and the most probable predator responsible for the perforations in the carapace that we found at SCNP (Fig. 3).

The two records we presented are complementary. The $T$. tricinctus individual in the video obtained in BdM was completely rolled up and thus, it may still be alive. Although this record does not show how and whether the predator fed on the prey or not, it demonstrates that $P$. onca exerts predation risk for $T$. tricinctus. The effects of predation risk should affect $T$. tricinctus population dynamics through the costs of antipredator behavioral responses (or risk effects), which can result in reduced survival, growth, or reproduction (Creel \& Christianson, 2008). The record from SCNP presents the actual removal of $T$. tricinctus individuals from its population, and the record from BdM indicates that $P$. onca may capture $T$. tricinctus individuals at one place to feed on them at another.

The consumption of Tolypeutes by $P$. onca has already been reported through the presence of $T$. matacus remnants in P. onca scats (Taber et al., 1997; McBride et al., 2010). Thus, the records we obtained add to previously available information on this interaction, by demonstrating that it also occurs with T. tricinctus and how it may occur for both Tolypeutes species. We believe that the $P$. onca predation behavior we reported here should be valid for both T. tricinctus and T. matacus, as these armadillos share similar biology (Medri et al., 2011).

Panthera onca individuals tend to present smaller body sizes in areas where the mean weight of its consumed prey is lower (Hoogesteijnt \& Mondollf, 1996). This appears to be the case of the Caatinga, where $P$. onca individuals present lower body mass than in floodplains and rainforests (Cláudia Bueno de Campos, personal communication; Hoogesteijnt \& Mondollf, 1996), as it is the mean weight of their consumed prey (Miranda et al., 2018). Although P. onca tends to avoid species as small as Tolypeutes spp. (Hayward et al., 2016), the smaller sizes of $P$. onca individuals in the Caatinga should reduce the individua's energy requirement, allowing them to feed more frequently (but not solely) on smaller species, especially if larger prey are less available (Miranda et al., 2018). Those individuals might also be less capable of successfully slaughtering larger prey.

Armadillos are shown to be consumed by $P$. onca according to their abundance (or availability) (Hayward et al., 2016). This might explain why T. matacus has already been found in higher frequency than $D$. novemcinctus and E. sexcinctus in P. onca scats (Taber et al., 1997; McBride 


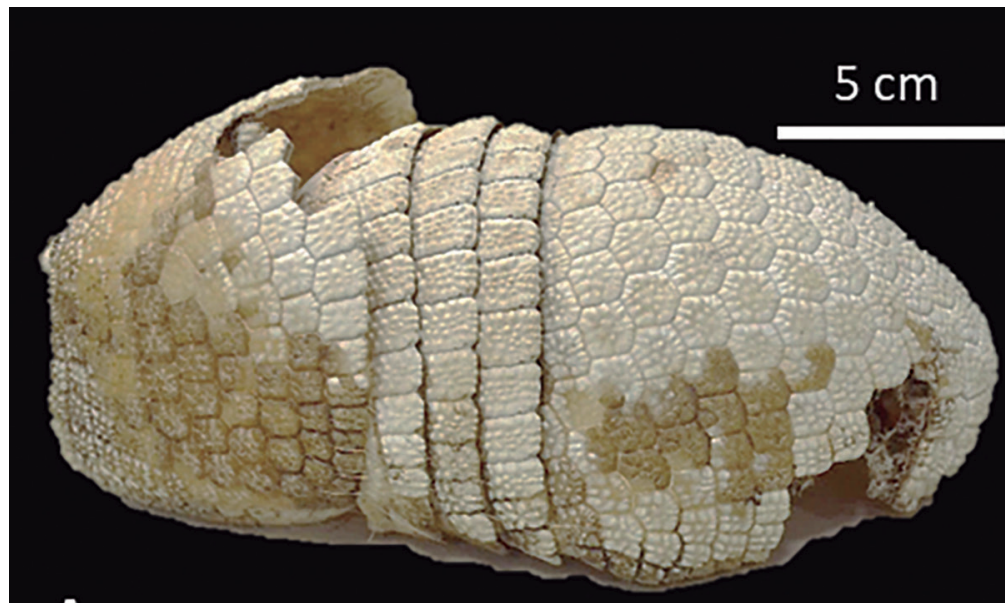

A

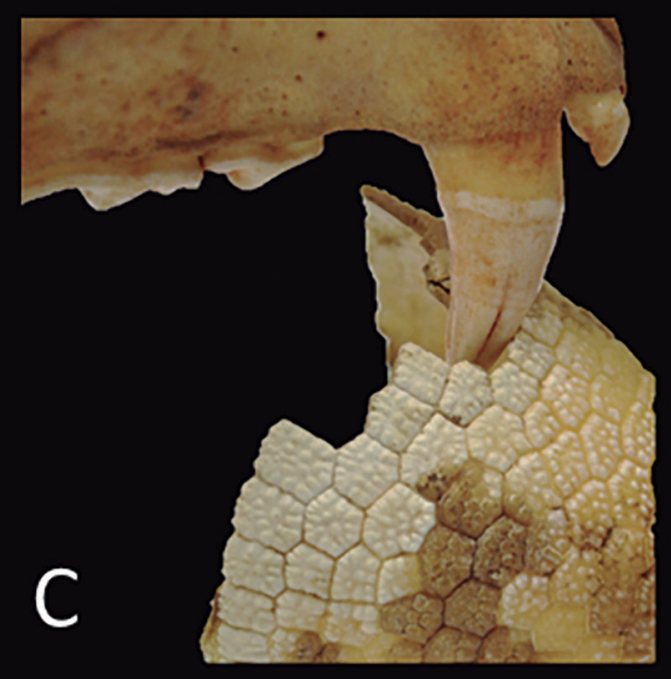

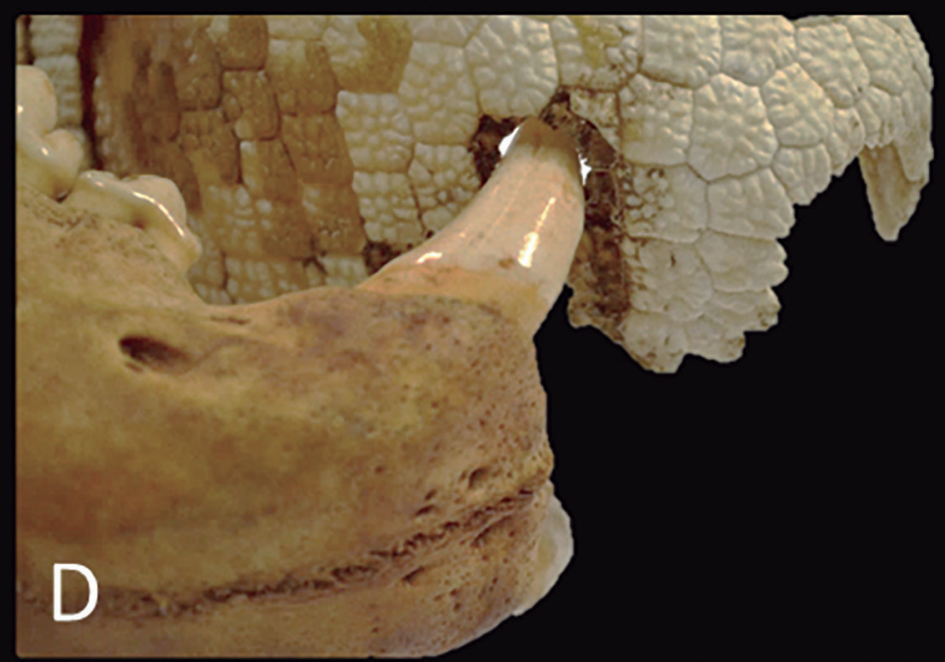

B
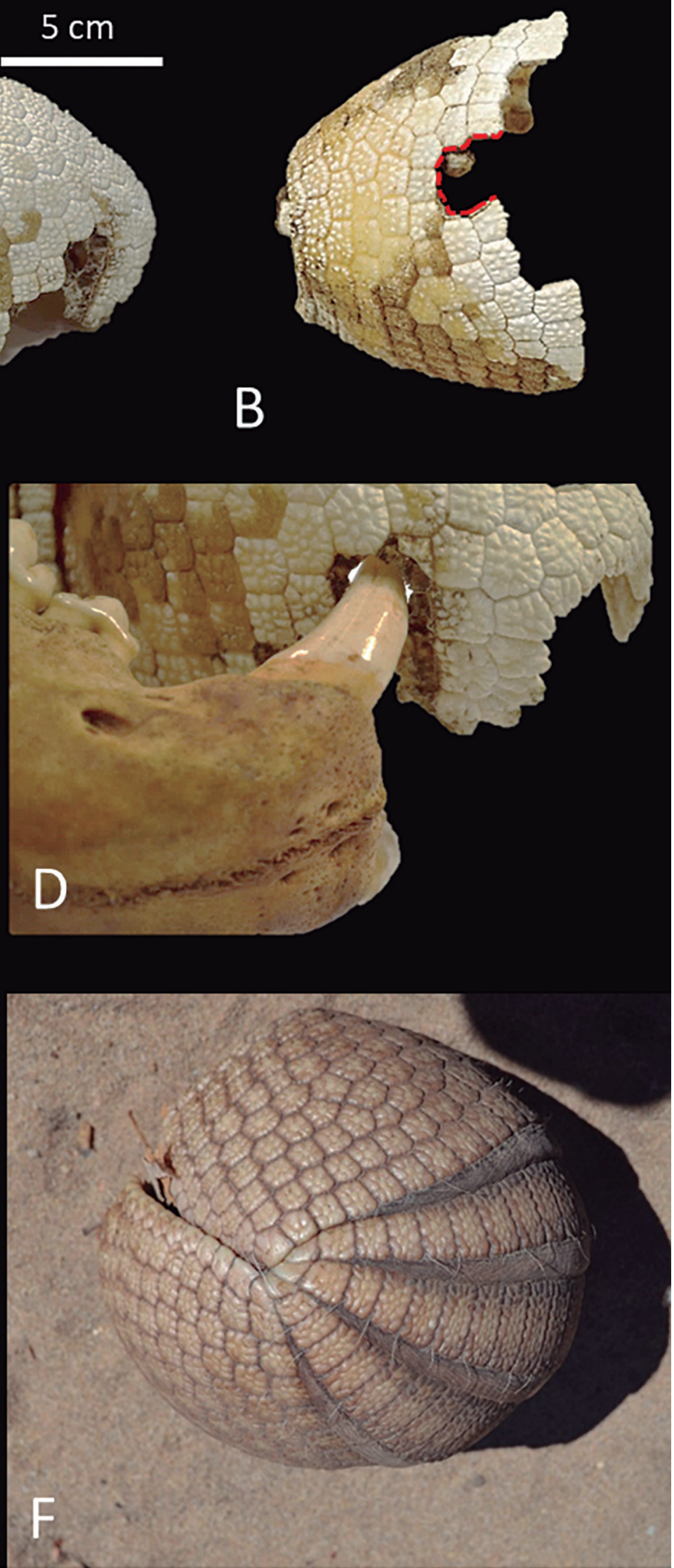

Figure 3. The carapace of an individual of Brazilian three-banded armadillo (Tolypeutes tricinctus) attacked by a jaguar (Panthera onca). (A) An overview of the carapace. (B) A close-up of the damaged scapular shield (broken scutes are circled in red). (C) The fitting of a $P$. onca canine tooth into a broken scute of the scapular shield. (D) The fitting of a $P$. onca canine tooth into the perforation in the pelvic shield. (E) The probable disposition of $P$. onca jaws during the bite, while respecting the maximum mandibular opening. (F) An individual of $T$. tricinctus rolled up parallel to the ground, demonstrating a possible position of the individual in which the bite could have occurred. 
et al., 2010). But, while it could be due to the higher availability of T. matacus, it could also be a consequence of the easiness for $P$. onca to prey on Tolypeutes spp., which is derived from its capacity to prey on armored animals (Meachen-Samuels \& van Valkenburgh, 2009; Miranda et al., 2016; Brito et al., 2018).

The inefficiency of Tolypeutes defense mechanism against $P$. onca predation might also make slaughtering these armadillos less energetically costly for $P$. onca individuals than other armadillos that rely on fleeing and digging burrows to escape predation. Depending on the relative availability of these prey, $P$. onca predation on Tolypeutes spp. could be expected not to be uncommon, and especially on T. tricinctus in the Caatinga.

In conclusion, the originality of the records we obtained is more likely to be a result of the negligence-driven scarceness of scientific research in the Caatinga (Santos et al., 2011) as well as in areas of the Cerrado where $P$. onca and $T$. tricinctus coexist than the rarity of this interaction. However, different factors may influence its occurrence, such as the population densities of these species, which may decrease due to overexploitation and habitat loss, even leading to local extinctions (Morato et al., 2013; Reis et al., 2015). Overall, our findings allow this interaction to be assessed in future research on the ecology of $P$. onca and $T$. tricinctus without further uncertainty about its existence.

\section{ACKNOWLEDGMENTS}

This work was funded by the Arizona Center for Nature Conservation (ACNC)/Phoenix Zoo (grants from years 2017 and 2019) and Rufford Foundation (23454-1, 2017). Azurit and Statkraft provided logistical support in BdM. The Comissão de Aperfeiçoamento de Pessoal do Nível Superior (CAPES) provided grants to R.A. Magalhães and L.M.M. Sena. The Conselho Nacional de Desenvolvimento Científico e Tecnológico (CNPq) provided grants to F.H.G. Rodrigues.

\section{AUTHORS' CONTRIBUTIONS}

RAM: Conceptualization, Funding acquisition, Investigation, Methodology, Project administration, Resources, Software, Validation, Visualization, Writing - original draft, Writing - review \& editing. LMMS: Conceptualization, Funding acquisition, Investigation, Methodology, Project administration, Resources, Validation, Writing - review \& editing. FHGR: Conceptualization, Funding acquisition, Investigation Methodology, Project administration, Resources, Supervision, Validation, Writing - review \& editing.

\section{REFERENCES}

Astete, S.; Marinho-Filho, J.; Machado, R.B.; Zimbres, B.; Jácomo, A.T.A.; Sollmann, R.; Tôrres, N.M. \& Silveira, L. 2017. Living in extreme environments: modeling habitat suitability for jaguars, pumas, and their prey in a semiarid habitat. Journal of Mammalogy, 98(2): 464-474. D0I

Bocchiglieri, A.; Mendonça, A.F. \& Henriques, R.P.B. 2010. Composição e diversidade de mamíferos de médio e grande porte no Cerrado do Brasil central. Biota Neotropica, 10: 169-176. DOI

Brito, E.S.; Miranda, E. \& Tortato, F.R. 2018. Chelonian predation by jaguars (Panthera onca). Chelonian Conservation and Biology, 17(2): 280-283. D0I

Christiansen, P. 2007. Comparative bite forces and canine bending strength in feline and sabretooth felids: implications for predatory ecology. Zoological Journal of the Linnean Society, 151(2): 423-437. D0I

Christiansen, P. \& Adolfssen, J.S. 2005. Bite forces, canine strength and skull allometry in carnivores (Mammalia, Carnivora). Journal of Zoology, 266(2): 133-151. DOI

Creel, S. \& Christianson, D. 2008. Relationships between direct predation and risk effects. Trends in Ecology and Evolution, 23(4): 194-201. D0I

Feijó, A.; Garbino, G.S.T.; Campos, B.A.T.P.; Rocha, P.A.; Ferrari, S.F. \& Langguth, A. 2015. Distribution of Tolypeutes Illiger, 1811 (Xenarthra: Cingulata) with comments on its biogeography and conservation. Zoological Science, 32: 77-87. D0I

Foster, R.J.; Harmsen, B.J.; Valdes, B.; Pomilla, C. \& Doncaster, C.P. 2010. Food habits of sympatric jaguars and pumas across a gradient of human disturbance. Journal of Zoology, 280(3): 309-318. DOI

Hayward, M.W.; Kamler, J.F.; Montgomery, R.A.; Newlove, A.; Rostro-García, S.; Sales, L.P. \& Van Valkenburgh, B. 2016. Prey preferences of the Jaguar Panthera onca reflect the post-Pleistocene demise of large prey. Frontiers in Ecology and Evolution, 3(148):1-19. D0I

Hoogesteijnt, R. \& Mondollf, E. 1996. Body mass and skull measurements in four jaguar populations and observations on their prey base. Bulletin of the Florida Museum of Natural History, 39(6): 195-219.

Instituto Brasileiro de Geografia e Estatística (IBGE). 2015. Malhas digitais. Available: https://mapas.ibge.gov.br/bases-e-referenciais/bases-cartograficas/ malhas-digitais. Access: 09/05/2020.

Instituto Nacional do Semiárido (INSA). 2014. Sistema de Gestão da Informação e do Conhecimento do Semimárido Brasileiro.

McBride, R., Giordano, A.\& Ballard, W.B. 2010. Note on the winter diet of jaguars Panthera onca in the Paraguayan Transitional Chaco. Bellbird, 4: 1-12.

Meachen-Samuels, J. \& van Valkenburgh, B. 2009. Craniodental indicators of prey size preference in the Felidae. Biological Journal of the Linnean Society, 96(4): 784-799. DOI

Medri, I.M.; Mourão, G.M. \& Rodrigues, F.H.G. 2011. Ordem Cingulata. In: Reis, N.R.; Peracchi, A.L.; Pedro, W.A. \& Lima, I.P. Mamíferos do Brasil. 2. ed. Londrina, Nelio R. dos Reis. p. 75-90.

Miranda, E.B.P.; Jácomo, A.T.D.A.; Tôrres, N.M.; Alves, G.B. \& Silveira, L. 2018. What are jaguars eating in a half-empty forest? Insights from diet in an overhunted Caatinga reserve. Journal of Mammalogy, 99(3): 724-731. DOI

Miranda, E.B.P.; Menezes, J.F.S. de \& Rheingantz, M.L. 2016. Reptiles as principal prey? Adaptations for durophagy and prey selection by jaguar (Panthera onca). Journal of Natural History, 50(31-32): 2021-2035. D0I

Morato, R.G.; Beisiegel, B.M.; Ramalho, E.E.; Campos, C.B. \& Boulhosa, R.L.P. 2013. Avaliação do risco de extinção da onça-pintada Panthera onca (Linnaeus, 1758) no Brasil. Biodiversidade Brasileira, 3: 122-132.

Novack, A.J.; Main, M.B.; Sunquist, M.E. \& Labisky, R.F. 2005. Foraging ecology of jaguar (Panthera onca) and puma (Puma concolor) in hunted and nonhunted sites within the Maya Biosphere Reserve, Guatemala. Journal of Zoology, 267(2): 167-178. D0I

Olmos, F. 1992. Serra da Capivara National Park and the conservation of north-eastern Brazil's Caatinga. Oryx, 26(3): 142-146. D0I

Reis, M.L.; Chiarello, A.G.; Campos, C.B.; Miranda, F.R.; Xavier, G.A.A.; Mourão, G.M.; Ohana, J.A.B.; Barros, N.M. \& Anacleto, T.C.S. 2015. Avaliação do 
risco de extinção de Tolypeutes tricinctus (Linnaeus, 1758) no Brasil. In: Instituto Chico Mendes de Conservação da Biodiversidade (ICMBio), Avaliação do risco de extinção dos xenartros brasileiros. Braślia, ICMBio. p. 237-248.

Sanderson, E.W.; Redford, K.H.; Chetkiewicz, C.L.B.; Medellin, R.A.; Rabinowitz, A.R.; Robinson, J.G. \& Taber, A.B. 2002. Planning to save a species: the jaguar as a model. Conservation Biology, 16: 58-72. DOI

Santos, J.C.; Leal, I.R.; Almeida-Cortez, J.S.; Fernandes, G.W. \& Tabarelli, M. 2011. Caatinga: the scientific negligence experienced by a dry tropical forest. Tropical Conservation Science, 4: 276-286. D0I

Silva, J.M.C.; Barbosa, L.C.F.; Leal, I.R. \& Tabarelli, M. 2017. The Caatinga: understanding the challenges. In: Silva, J.M.C.; Leal, I.R.; Tabarelli, M., Caatinga: the largest Tropical dry forest region in South America. Cham, Springer. p. 3-19.
Superina, M. \& Loughry, W.J. 2012. Life on the half-shell: Consequences of a carapace in the evolution of armadillos (Xenarthra: Cingulata). Journal of Mammalian Evolution, 19(3): 217-224. DOI

Superina, M.; Pagnutti, N. \& Abba, A.M. 2014. What do we know about armadillos? An analysis of four centuries of knowledge about a group of South American mammals, with emphasis on their conservation. Mammal Review, 44: 69-80. DOI

Taber, A.B.; Novaro, A.J.; Neris, N. \& Colman, F.H. 1997.The food habits of sympatric jaguar and puma in the Paraguayan Chaco. Biotropica, 29(2): 204-213. Available: http://www.jstor.com/stable/2389036. Access: 16/06/2020.

Wetzel, R.M.; Gardner, A.L.; Redford, K.H. \& Eisenberg, J.F. 2008. Order Cingulata. In: Gardner, A.L., Mammals of South America. Volume 1: Marsupials, xenarthrans, shrews and bats. Chicago, University of Chicago Press. p. 128-156. 